\title{
KEBERADAAN PANTI JOMPO DALAM MASYARAKAT DAN BUDAYA ACEH (SUATU ANALISIS SOSIOLOGIS)
}

\author{
IRMA JURAIDA \\ JURUSAN SOSIOLOGI \\ FALKULTAS ILMU SOSIAL DAN POLITIK \\ UNIVERSITAS TEUKU UMAR \\ Irmajuraida2@gmail.com
}

\begin{abstract}
This study discusses how the existence of the Jambo Home in the Society and Culture of Aceh is known to be religious and cultured. In the Acehnese society and culture itself, children still feel obligated and have loyalty to abandon their parents who can not take care of themselves. Values and culture prevailing in society, children are obliged to give affection to their parents .. The problem in this research is how the existence of Panti Jompo in Aceh society culture. This study uses a qualitative approach, mainly through in-depth interview techniques with face-to-face and observation. This paper aims to explore the understanding of a habit, the socio-religious and cultural values of the people of Aceh towards Janti Jompo.The results of this study indicate that the Nursing Home in the culture of the people of Aceh is more determined by the interaction (knowledge) of social background, culture and religious values which is shared by a person or group in Aceh society.
\end{abstract}

Key Words: Nursing Home, Culture, People of Aceh

\section{PENDAHULUAN}

Masalah kesejahteraan sosial dalam masyarakat akhir-akhir ini semakin mendapatkan perhatian pemerintah, tidak hanya masalah kesejahteraan bagi anakanak di bawah umur yang mempunyai masalah sosial-ekonomi dengan membangun program panti asuhan untuk meningkatkan kesejahteraan sosial. Masalah kesejahterahteraan sosial bagi lansia juga semakin mendapat perhatian pemerintah dan masyarakat, terutama di Indonesia yang menganut paham negara kesejahteraan (welfare) dengan model partisipasi.

Salah satu usaha pemerintah untuk meningkatkan kesejahteraan sosial bagi lansia yang terlantar dan mempunyai masalah sosial-ekonomi dalam masyarakat, 
yaitu dengan mendirikan panti jompo melalui Undang-Undang Republik Indonesia Nomor 13 Tahun 1998 Tentang Pemberian Bantuan Penghidupan Orang Jompo. Panti jompo merupakan aplikasi nyata dari konsep negara kesejahteraan dengan moodel partisipasi. Hal ini menekankan bahwa pemerintah tetap mengambil bagian dalam penanganan masalah sosial dan penyelenggaraan jaminan sosial (James Midgley, 2005:182).

Panti jompo merupakan contoh kerja sama yang baik antara pemerintah (state) dan masyarakat (civil society) dalam rangka meningkatkan kesejahteraan sosial yang sasaran utamanya adalah para lansia yang mempunyai masalah sosio-ekonomi baik dalam keluarganya maupun masyarakat. Hal ini merupakan kewajiban negara untuk menjaga dan memelihara setiap warga negaranya. Sebagaimana tercantum dalam UU No. 12 Tahun. 1996 ( Direktorat Jenderal, Departemen Hukum dan HAM). (www. Cybertokoh.com/bacaan / wanita/panti jompo).

Oleh karena itu, diperlukan upaya-upaya sosialisasi lain dalam masyarakat (society) melalui proses interaksi diri dengan masyarakat, mind yang memungkinkan terbangun alternatif sistem nilai-budaya (cultural-value system) yang membentuk konsep diri (self) yang berupa pemahaman mereka terhadap suatu fenomena (keberadaan panti jompo) secara komprehensif. Program pemerintah (panti jompo) sebagai lembaga sosial yang telah dipahami oleh sebagian besar masyarakat Aceh sebagai solusi memberi peluang bagi tumbuhnya persepsi yang objektif sebagai hasil kontruksi sosial budaya yang kondusif.

Peningkatan dalam tingkat harapan hidup manusia memang patut untuk disyukuri, namun di sisi lain kondisi ini menimbulkan polemik baru dalam kehidupan bermasyarakat maupun berkeluarga. Untuk mengatasi salah satu dari berbagai persoalan lansia, pemerintah dalam hal ini Departemen Sosial mengupayakan suatu wadah atau sarana untuk menampung lansia dalam satu institusi yang disebut dengan panti jompo. Di sinilah penting adanya panti jompo sebagai tempat untuk pemeliharaan dan meningkatkan kesejahteraan sosial bagi lansia yang tetap dapat memelihara kehidupan bermasyarakat.

Salah satu sisi positif panti jompo dalam kehidupan masyarakat adalah sebagai tempat bersosialisasi sesama lansia sehingga dapat membuat lansia tidak merasa kesepian atau merasa dibuang oleh keluarga maupun masyarakat. Selain itu juga dipanti jompo ini lansia banyak memiliki atau dilibatkan dalam sebuah aktifitas yang melibatkan fisik dan mentalnya agar selalu terjaga, juga sebagai sarana penghibur, seperti senam sehat, melakukan hobi seperti kerajinan tangan atau sekedar membaca. Panti jompo adalah suatu tempat yang akan menjadi tempat perkembangan interaksi sosial, dikarenakan mereka akan hidup bersama dengan sesama lanjut usia.

Panti jompo sebagai suatu program pemerintah dalam rangka meningkatkan kesejahteraan sosial bagi masyarakat seharusnya dipandang sebagai suatu solusi dan memiliki nilai positif dalam kehidupan masyarakat. Namun pada kenyataannya sampai saat ini sebagian masyarakat Aceh, panti jompo masih dipandang dan bercitra 
agak negatif. Selain karena tempatnya yang di konotasikan dengan kekumuhan, panti jompo juga di sebut-sebut sebagai tempat pembuangan lansia.

Sebagian masyarakat masih berpersepsi (pemahaman) keberadaan lembaga penampungan orang lanjut usia atau panti jompo dinilai sebagai tindakan mengebiri adat dan kearifan lokal ke-Acehan. Maksudnya, terlalu naif bagi masyarakat Aceh yang masih begitu menjunjung tinggi nilai-nilai hingga simbol-simbol ke-Islaman, adalah mustahil menyerahkan orangtuanya ke panti jompo agar diasuh oleh pemerintah.

Pada masyarakat dan budaya Aceh sendiri, anak masih merasa berkewajiban dan mempunyai loyalitas menyatuni orangtua mereka yang sudah tidak dapat mengurusi dirinya sendiri. Nilai dan kebudayaan yang berlaku dalam masyarakat, anak wajib memberikan kasih sayang kepada orangtuanya. Para lansia sendiri juga mempunyai peranan yang menonjol sebagai orang yang "dituakan",bijak dan berpengalaman, pembuat keputusan, dan kaya pengetahuan baik dalam keluarga maupun dalam masyarakat. Mereka sering berperan sebagai model bagi generasi muda, walaupun banyak diantara mereka tidak mempunyai pendidikan formal (T.O. Ihromi, 2004:193).

Realitas di atas menggambarkan pemahaman yang berbeda terhadap keberadaan panti jompo dalam masyarakat bersangkutan sesuai dengan penafsiran (melalui proses pemikiran yang membentuk konsep diri) Mereka terhadap panti jompo tersebut yang memberi nilai tersendiri dalam kehidupan berkeluarga maupun bermasyarakat. Berdasarkan permasalahan di atasmaka tulisan ini mencoba menjelaskan tentang Keberadaan Panti Jompo Dalam Masyarakat Dan Budaya Aceh

\section{KERANGKA TEORI}

Penelitian ini menggunakan kerangka teori interaksionisme simbolik yang dikembangkan oleh George Herbert Mead. Mead dalam konsepsinya tentang interaksionisme simbolik mengadopsi teori dari sosiolog klasik Max Weber yang dalam teorinya juga menganalisis tindakan individu. Tokoh filosof lain yang mempengaruhi Mead adalah John Dewey dalam orientasi sosiologi yang di kembangkan oleh Mead, yaitu Pertama, menurut pemikir pragmatisme, realitas sebenarnya tak ada "di luar" dunia nyata; realitas "di ciptakan secara aktif saat kita bertindak didalam dan terhadap dunia nyata". Kedua, manusia mengingat berdasarkan pengetahuan (pemikiran) mereka mengenai dunia nyata pada apa yang telah terbukti berguna bagi mereka. Ketiga, manusia mendefinisikan "objek" sosial dan fisik yang mereka temui di dunia nyata menurut kegunaanya bagi mereka. Keempat, bila kita ingin memahami aktor, kita harus mendasarkan pemahaman itu di atas apa-apa yang sebenarnya mereka kerjakan dalam dunia nyata (Ritzer, 2008: 266).

Menurut Mead ada tiga hal yang penting bagi interaksionisme simbolik: (1) memusatkan perhatian pada interaksi antara aktor dan dunia nyata; (2) memandang 
baik aktor maupun dunia nyata sebagai proses dinamis dan bukan sebagai struktur yang statis, (3) dan arti penting yang dihubungkan kepada kemampuan aktor untuk menafsirkan kehidupan sosial. Menurut Mead manusia mempunyai sejumlah kemungkinan tindakan dalam pemikirannya sebelum ia memulai tindakan yang sebenarnya terlebih dahulu memilih berbagai altenatif tindakan itu secara mental melalui pertimbangan pemikiranya (Ritzer, 1985: 67).

Mead dalam karyanya Mind, Self and Society, berpendapat bahwa bukan pikiran yang pertama kali muncul, melainkan masyarakatlah yang terlebih dulu muncul dan baru diikuti pemikiran yang muncul dalam masyarakat sebagai proses interaksi antar individu. Analisa Mead ini mencerminkan fakta bahwa masyarakat atau yang lebih umum disebut kehidupan sosial menempati prioritas dalam analisanya, Mead selalu memberi prioritas pada dunia sosial dalam memahami pengalaman sosial karena keseluruhan kehidupan sosial mendahului pikiran individu secara logis maupun temporer. Individu yang berpikir dan sadar diri tidak mungkin ada sebelum kelompok sosial. Kelompok sosial hadir lebih dulu dan dia mengarah pada perkembangan kondisi mental-diri individu (Ritzer,2008 : 273).

Secara teoritis terjadinya interaksi sosial tidak hanya tergantung dari tindakan sosial tetapi juga tergantung kepada adanya tanggapan terhadap tindakan tersebut. Dan aspek terpenting dari tindakan adalah bila seseorang memberi tafsiran pada perilaku orang lain. Menurut Karp dan Yoels, simbol atau tindakan mengarahkan kepada tanggapan-tanggapan (pemahaman) terhadap tindakan tersebut dan memberi tafsiran pada sesuatu atau perilaku orang lain Sunarto (dalam J.Dwi Narwoko, 2004: 17 ).

Menurutorientasisosiologis yang dikembangkan oleh Mead. Pertama, menurut pemikir pragmatisme, realititas sebenarnya tak berada "di luar" dunia nyata, realitas "diciptakan secara aktif saat kita bertindak di dalam dan terhadap dunia nyata", kedua, manusia berfikir berdasarkan pengetahuan (pemahaman) mereka mengenai dunia nyata pada apa yang telah terbukti berguna bagi mereka. Menurut Mead ada tiga hal yang penting bagi interaksionisme simbolik, yaitu: (1) memusatkan perhatian pada interaksi antara aktor dan dunia nyata; (2) memandang baik aktor maupun dunia nyata sebagai proses dinamis, (3) arti penting yang dihubungkan kepada kemampuan aktor untukmenafsirkankehidupansosial.

Mead melihat suatu fenomena itu ada hubungannya terhadap apa yang terjadi antara stimulus dan respon, Bernard Meltzer merangkum pemikiran Mead : Menurut Mead, unit studi adalah "tindakan" yang terdiri dari aspek tersembunyi dan yang terbuka dari tindakan manusia. Di dalam tindakan itulah semua perhatian, persepsi, imajinasi, alasan, emosi, dan sebagainya dilihat sebagai bagian dari tindakan, karenanya tindakan meliputi keseluruhan proses yang terlibat dalam aktivitas manusia (masyarakat) (Ritzer, $2008: 268$ ).

Dengan kerangka analisis di atas dimaksudkan bahwa untuk memperoleh pemahaman masyarakat mengenai keberadaan panti jompo dilakukan observasi- 
Community: Volume 4, Nomor 1, April 2018

ISSN: $2477-5746$

partisipasi dan wawancara mendalam dengan para informan. Pengalaman dan pemahaman mereka berdasarkan pemikiran, konsep diri yang berkembang melalui sosialisasi dalam masyarakat dan proses penafsiran sosial terhadap suatu tindakan dan permasalahan (keberadaan panti jompo) dibutuhkan untuk mendapatkan tingkat pemahaman objektif dan subjektif. Hal ini disebabkan titik-tolak yang dijadikan patokan adalah pemahaman dari perdenifisian (proses pemikiran) sosial atas keberadaan panti jompo yang berkembang dalam pemikiran masyarakat Aceh.

\section{METODE PENELITIAN}

Menurut Arnold (dalam Bagong: 2008) metode penelitian sangat diperlukan dalam suatu penelitian ilmu sosial mengingat fakta-fakta sosial tidak tergeletak dan sudah "siap pakai" begitu saja, tinggal menunggu untuk diambil. Melainkan, faktafakta sosial itu harus dibuka dari "kulit pembungkus" kenyataan yang sepitas tampak, harus diukur dengan tepat, dan harus diamati pula pada suatu fakta yang dapat dikaitkan dengan fakta-fakta lain yang relevan (Suryanto: 2008). Pendekatan dan Jenis Penelitian, Penelitian ini menggunakan pendekatan kualitatif dengan jenis penelitian yang bersifat deskriptif. Penelitian ini difokuskan pada pemahaman masyarakat Aceh terhadap keberadaan panti jompo daam kultur masyarakat Aceh.

\section{TEMUAN DAN PEMBAHASAN}

Pada bagian terdahulu sudah dikemukakan bahwa kerangka konseptual pemahaman sosial yang digunakan dalam penelitian ini didasarkan pada pengetahuan dan pemahaman masyarakat sebagai hasil pendefinisian sosial budaya masyarakat. Keberadaan panti jompo di asumsikan sebagai suatu gejala subjektif dan objektif, sebagai pemahaman warga masyarakat dari segi pandangan suatu proses atau seretetan tahapan yang berlangsung secara terus menerus berdasarakan proses pemikiran (mind), diri (self) dan masyarakat (society). Dengan kata lain, pemahaman masyarakat terhadap panti jompo didasarkan pada pengetahuan mereka tentang panti jompo melalui seretetan tahapan di atas.

Pemahaman tersebut dilandasi pada asumsi bawah pemikiran (mind) tentang panti jompo yang berkembang dalam masyarakat membentuk self melalui proses sosialisasi sebagai momen internalisasi dalam masyarakat (society). Realitas sosial tersebut dapat ditemukan dalam hubungan warga masyarakat individual dengan institusi atau lembaga sosial (panti jompo) yang telah menjadi kebutuhan individu secara bersama-sama (Soekanto, 2007:171). Panti jompo sebagai lembaga social (social institution) adalah program pemerintah dalam rangka meningkatkan kesejahteraan sosial bagi masyarakat khususnya bagi lansia yang terlantar dan mempunyai masalah sosio-ekonomi dalam keluarga maupun masyarakat. Oleh karena itu, panti jompo 
dapat dipersepsikan sebagai suatu realitas subjektif dan objektif yang dipahami manusia sebagai hasil interaksi manusia dengan realitas sosial (Berger, 1990:21).

Wawancara dengan salah satu informan melalui pertanyaan, bagaimanakah menurut masyarakat yang sangat kental dengan adat-istiadat dan sebagian mereka masih sangat fanatik terhadap ajaran agama mengenai "berbakti kepada kedua orang tua" memahami dan memberi makna keberadaan panti jompo? Adapun jawaban yang diperoleh ialah bahwa berdasarkan pengetahuan dan pemahamannya menunjukan bahwa secara umum tidak ada masalah terhadap keberadaan panti jompo, itu sangat bagus keberadaannya dan menjadi sebuah solusi karena panti jompo tersebut, sudah menjadi institusi yang sangat cocok dalam membantu masyarakat yang sudah lanjut usia dan terlantar atau tidak ada sanak saudara yang mengurusnya dan mempunyai masalah sosial-ekonomi dalam keluarga maupun dalam masyarakat.

Lebih jauh menurut masyarakat Aceh bahwa pada umumnya orang tua dalam sebagian masyarakat tidak ditempatkan di situ (di dalam panti jompo), dengan alasan karena kita harus menghormati orang tua. Jadi kalau orang tua yang sudah jompo tinggal di situ seolah-olah anak tidak memperdulikannya, apa lagi kalau anak sudah sukses. Pada umumnya penghuni panti jompo berasal dari berbagai daerah di Aceh. Meskipun begitu masyarakat bersangkutan sudah menunjukan bahwa dalam pemahamannya melalui seretetan tahapan (mind, self and society) terhadap keberadaan panti jompo secara sosiologis sudah mengalami proses legitimasi atau pembenaran dalam masyarakat bersangkutan (Beger, 1990:132).

Hal ini senada dengan yang diungkapkan oleh seorang informan lain, bahwa kehadiran panti jompo di Aceh tidak begitu menarik. Hal ini disebabkan pemahaman yang demikian itu lebih cenderung sempit dan di dasarkan pada semangat fanatisme terhadap ajaran agama. Salah satu implikasi dari pemahaman yang demikian itu, bahwa masyarakat akan berpandangan negatif jika ada anak yang mengirimkan orang tuanya ke panti jompo. Anak tersebut dianggap anak yang tidak berbakti kepada orangtuanya, bahkan dianggap durhaka oleh masyarakat. Namun jika ada lansia yang tidak mempunyai anak atau kerabat (orang-orang tua berumur lanjut yang terlantar) dan lansia yang mempunyai masalah sosio-ekonomi, maka lebih tepat mereka itu dirawat di panti jompo. Oleh karena itu, masyarakat harus melihat keberadaan panti jompo ini secara komprehensif dan objektif (sebagai solusi).

Nilai ke-keluargaan yang dipegang erat oleh sebagian besar masyarakat Aceh menjadi salah satu alasan mengapa rumah jompo atau panti jompo bukan menjadi suatu pilihan tempat penitipan kaum lansia. Solusi penempatan atas anggotakeluarga yang sudah berumur lanjut untukmendapatkan pelayanan, baik secara sosial maupun ekonomis (lahir dan bathin) ke rumah jompo dianggap sebagai perbuatan yang tidak terpuji. Ketakutan dan kekhawatiran melakukan kesalahan atau melanggar nilai dan norma-norma yang di yakini dalam suatu masyarakat adalah bagian status quo dan ada kekhawatiran atas sistem nilai-budaya dan adat istiadat yang mengancam anggota masyarakat (sanksi sosial). 
Masyarakat memahami dan mempersepsikan keberadaan panti jompo relatif tergantung pada pandangan pribadi keluarga masing-masing, seperti ungkapan berikut ini:

"ureueng Aceh nyoe ladom sifet jih e'k cire't ka dipoe mantong peutheuen gengsi, kedroe $h^{\prime} a n$ ek ta urueh, na fasilitas negara, na peutugas yang ditetapkan le' negara tan ta manfaatkan. ataupun keunan h'an geuba, le that sifuet ureueng Aceh cit lage'enyan e'k cire't ka dipoe gengsi mantong peutheuen nyan cit ka wata'k ureueng tanyo". Artinya sebagian orang Aceh sangat mempertahankan harga dirinya, meskipun sudah tidak mampu mengurusnya tetap saja tidak mau memanfaat panti jompo sebagai solusi.Mempertahankan gengsi itu memang watak orang Aceh."

Sebagian masyarakat Aceh memiliki sifat dan watak yang keras dalam mempertahankan idealismenya, meskipun keberadaan panti jompo sangat dibututuhkan sebagai lembaga sosial dalam rangka meningkatkan kesejahteraan sosial dan membantu lansia yang mempunyai masalah sosio-ekonomi, baik dalam keluarganya maupun masyarakat. Kendatipun demikian panti jompo sebagai program pemerintah dalam masyarakat Aceh masih dianggap memiliki fungsi laten (lembaga yang kurang di akui dalam masyarakat). jadi, alangkah ruginya kalau ada masyarakat yang memang membutuhkan pelayanan yang lebih, tetapi pihak keluarga tidak mampu mengurusnya.

Pendapat lain menyatakan bahwa karakter masyarakat Aceh dalam mempertahankan idealismenya yang menjadi salah satu sebab masyarakat itu mempersepsikan panti jompo secara sempit. Karakter itu adalah suatu sifat struktural yang telah melekat pada cara berpikir dan cara bertindak homogen, tidak cukup mampu memberikan toleransi pada sesama warga masyarakat yang mengikuti cara berfikir dan cara bertindak heterogen. Suatu sistem nilai-budaya yang sudah mapan dan dipelihara dengan berbagai reward-funishment dalam masyakat Aceh dipandang sebagai mekanisme kontrol yang kondusif.

Keberadaan panti jompo dipandang masyarakat lebih cenderung sebagai suatu tempat penyantunan atau kewajiban pemerintah dalam memelihara kesejahteraan sosial bagi lansia yang mempunyai masalah sosial-ekonomi. Panti jompo kurang mendapatkan perhatian dan dukungan dari sebagian masyarakat, utamanya kalangan masyarakat yang masih berpikiran tradisional dan mempertahankan idealismenya dalam memahami keberadaan panti jompo. Hal ini antara lain disebabkan pemahaman masyarakat bersangkutan tentang panti jompo lebih didasarkan pada pemahaman ajaran agama yang fanatisme.

Lebih jauh masyarakat Aceh mengemukakan melalui wawancara mendalam dengan peneliti bahwa menurutnya pemahaman dan ajaran agama yang di hayati masyarakat memberi pengaruh terhadap pemahaman seseorang, seperti ungkapan berikut ini: 
"seubeutoi jih lam agama cit geuyoe berbakti keupada kedua droe ureueng tuha, pajan cit ta berbakti keh dua ureueng tuha, ureueng tuha tanyo geu kandung sikureueng bulen, geu sapih dua thon dan geupelihara geutanyo, na geu lakei bayeue kan gratis, oh leh nyan geebina tanyo sampei rayeuk, jak sikula dan segala macam kan mandumnyan h'na geulakei ungkoh. Cuman nyankeuh h'ana mandum ureueng Aceh lage'eenyan sifat jih."

Artinya, sebenarnya dalam pemahaman agama memang ada suruhan agar mereka berbakti kepada kedua orang tua, kapan juga seorang anak kepada kedua orang tua, orang tua sudah mengandung sembilan bulan, ibu menyusui dua tahun serta memelihara kita, tidak sedikitpun diharap balasan oleh orang tua, setelah itu di sekolahkan dan sebagainya orang tua kita tidak sedikitpun mengharapkan balasan. Jadi apalah arti pengabdian seorang anak terhadap kedua orang tua.

Pemahaman terhadap keberdaan panti jompo ditafsirkan atau di beri makna dengan sangat baik oleh seketaris gampong lamglumpang melalui wawancara mendalam dengan peneliti Menurutnya, masyarakat lamglumpang memahami keberadaan panti jompo dengan sangat objektif, setelah mengalami proses diskusi dengan berbagai pihak, keberadaannya menurut mereka sangat baik dalam membantu masyarakat khususnya lansia yang tidak ada yang mengurus (terlantar) serta lansia yang mempunyai masalah sosio-ekonomi dalam keluarga maupun masyarakat.

Berdasarkan dari hasil penelitian dapat di simpulkan bahwa masyarakat Aceh mengetahui dan memahami keberadaan panti jompo sebagai program pemerintah untuk meningkatkan kesejahteraan sosial bagi masyarakat khususnya bagi lansia yang memiliki kriteria tertentu. Kebanyakan kriteria yang dipaparkan mereka lebih cenderung bernuasa kapasitas sosio-ekonomis (terlantar, mempunyai masalah sosial) dalam keluarga maupun masyarakat. Kondisi seperti ini terlihat bahwa pemahaman masyarakat tentang panti jompo pada dasarnya terbentuk berdasarkan pengetahuan (mind) seorang individu (self) yang terbentuk dalam realitas sosial (soceity) mengenai keberadaan panti jompo (social institution).

\section{KESIMPULAN}

Pemahaman sosial (masyarakat) Aceh terhadap keberadaan panti jompo lebih banyak ditentukan oleh pemahaman dan pengetahuan seseorang atau kelompok (masyarakat) melalui seretetan tahapan pemikiran yang berkembang dalam masyarakat yang di pengaruhi oleh latar-belakang sosial, budaya yang membentuk konsep diri seseorang melalui proses sosialisasi nilai dan norma-norma yang berkembang dalam masyarakat bersangkutan.

Gambaran tersebut di atas adalah untuk menunjukan bahwa panti jompo sebagai sebuah solusi dalam mengatasi masalah lansia yang terlantar, dalam rangka meningkatkan kesejahteraan masyarakat. Dari batasan di atas dapat diketahui bahwa pelayanan panti jompo merupakan wujud dari fungsi lembaga kesejahteraan sosial 
Community: Volume 4, Nomor 1, April 2018

ISSN: 2477-5746

dalam menangani berbagai masalah kesejahteraan sosial bagi lansia atau orang tua jompo.

\section{DAFTAR PUSTAKA}

\section{Buku-Buku}

Berger, L, Peter dan Thomas Luckmann, 1990, Tafsir Sosial atas Kenyataan, Jakarta: LP3ES.

Craib, Ian, 1986, Teori-Teori Modern: dari Parson sampaiHabermas, Jakarta: RinekeCipta.

Johnson,Doeyle Paul, 1988, Teori Sosiologiklasikdan Modern, AlihBahasa : Robert Lawang, Jakarta : P.T, GramediaPustakaUtama, Jilid II.

Majid, Adnan, 2009, Kamus Aceh, Indonesia, inggris, Banda Aceh NAD-Indonesia: Boebon Jaya.

Midgle, James, 2005, Pembangunan Sosial Perspektif Pembangunan Dalam Kesejahteraan Sosial, Jakarta : Ditperta slam Departemen Agama R I.

Moleong, Lexy J, 2007, Metodologi Penelitian Kualitatif, Bandung : P.T Remaja Rosdakarya.

Narwoko, Dwi J, dan Suyanto, Bagong, 2004, Sosiologi : Teks Pengantar dan Terapan, Jakarta: Rineke Cipta.

Ritzer, George dan Douglas J. Goodman, 2008, Teori Sosiologi Modern. Edisi ke-6, Jakarta: Kencana.

1985, Sosiologi Ilmu Pengetahuan Berparadigma Ganda. Jakarta: CV. Rajawali.

Sunarto, Kamanto, 2004, Pengantar, Jakarta: Lembaga Penerbit Fakultas Universitas Indonesia.

T,O, Ihromi, 2004, Bunga Rampai Sosiologi Keluarga, Jakarta : Yayasan Obor Indonesia.

\section{Situs Internet/ Website}

Eriza.Pilihan Mengasuh Lansia di Rumah sendiri, www, Gemabaiturahman . Com/.../ pilahan-mengasuh-lansia-di-rumah, (online) 